\title{
CATALYST DEVELOPMENT FOR THE SELECTIVE METHYLATION OF CATECHOL
}

\author{
S. PORCHET, L. KIWI-MINSKER, R. DOEPPER, A. RENKEN \\ Institut de Génie Chimique, Ecole Polytechnique Fédérale de Lausanne, \\ CH-1015 Lausanne, Switzerland
}

\begin{abstract}
Gas-phase alkylation of catechol with methanol on $\gamma$-alumina and modified $\gamma$-alumina catalysts is studied experimentally. By limiting the conversion to $\mathrm{X}<0.3$, the formation of polymethylated species can be avoided and only the three isomers guaiacol, 3-methylcatechol and 4-methylcatechol are observed. Optimising the catalyst composition and the reaction conditions, a selectivity of 0.75 for the industrially most valuable product 3-methylcatechol can be obtained.
\end{abstract}

\section{INTRODUCTION}

Synthesis of alkylcatechols is an important process in fine chemicals production. These substances are widely used in the synthesis of flavouring agents, agricultural chemicals and pharmaceuticals (Fiege et al., 1991). Previously $\gamma-\mathrm{Al}_{2} \mathrm{O}_{3}$ was found to be an effective catalyst for the gas-phase methylation of catechol with methanol as methylation agent (Porchet et al., 1993). The reaction leads to many different alkylated products. The reaction conditions have been optimised to avoid the formation of polymethylated products.

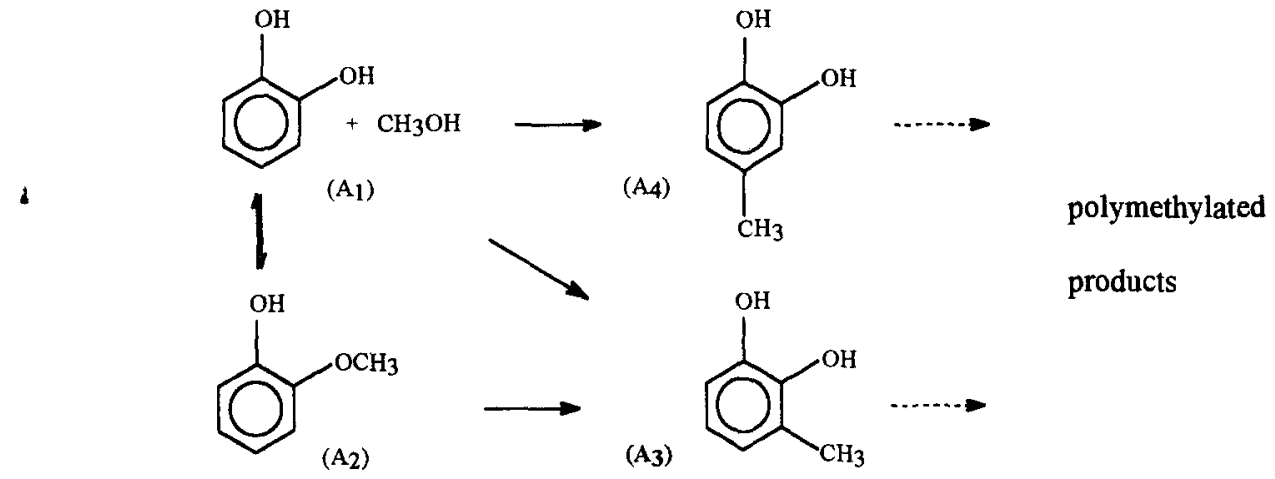

Fig.1 Reaction scheme of catechol methylation

The three primary products are guaiacol $\left(A_{2}\right), 3$-methylcatechol $\left(A_{3}\right)$, 4-methylcatechol $\left(A_{4}\right)$; they are formed by primary methylation of catechol $\left(A_{1}\right)$. At low conversion and in the temperature range of $260-310^{\circ} \mathrm{C}$, the oxygenalkylation is favoured, e. g. the main product is guaiacol. The carbon-alkylation is mainly ortho-selective.

Previous studies of phenol alkylation with methanol showed that this type of reaction is very sensitive to the acidic and basic properties of the catalyst surface (Tanabe et al., 1976; Velu et al., 1994). Different metal ions as $\mathrm{Ca}^{2+}, \mathrm{K}^{+}, \mathrm{Li}^{+}, \mathrm{Mg}^{2+}$ or ions as $\mathrm{B}^{3+}$ and $\mathrm{F}^{-}$are added to $\gamma$-alumina in order to modify these surface properties (Lercher et al., 1984; Berteau et al., 1987, 1989; Jurczyk et al., 1989). The purpose of this work is to increase the selectivity for the 3-methylcatechol through a catalyst modification.

\section{EXPERIMENTAL}

\section{Catalysts preparation}

Pure $\gamma$-alumina (Al-3982, Engelhard, NL) is used as starting material. The modified catalysts are prepared by wet capillary impregnation with aqueous solutions of nitrate salts. $\mathrm{H}_{3} \mathrm{BO}_{3}$ and $\mathrm{NH}_{4} \mathrm{~F}$ solutions are used in the case of $\mathrm{B}^{3+}$ and $\mathrm{F}^{-}$impregnation. 
The concentration of the solutions are adjusted to get the required ratio ion $/ \mathrm{Al}^{3+}$ (atomic-\%) by varying the amount of nitrates added to $\gamma$-alumina. Before impregnation, $\gamma$-alumina is dried at $200^{\circ} \mathrm{C}$ for 2 hours. After 8 hours at $50^{\circ} \mathrm{C}$ the impregnated samples are calcinated in air during 8 hours at $620^{\circ} \mathrm{C}$.

Apparatus and catalytic test

The reactants are premixed with water and the solutions are fed into the evaporator using a micro-feed pump. The catalytic reaction is carried out in the temperature range of $260-310^{\circ} \mathrm{C}$ and at $101.3 \mathrm{kPa}$ in a stainless steel tubular fixed-bed reactor (Fig. 2). To change the residence time in the reactor, the molar inlet flow $\left(F_{0}\right)$ and the catalyst mass $\left(\mathrm{m}_{\text {cat }}\right)$ are varied in the range of $5 \cdot 10^{-2}<\mathrm{F}_{0}<10 \mathrm{~mol} \cdot \mathrm{h}^{-1}$ and $2 \cdot 10^{-2}<\mathrm{m}_{\text {cat }}<3 \cdot 10^{-1} \mathrm{~kg}$.

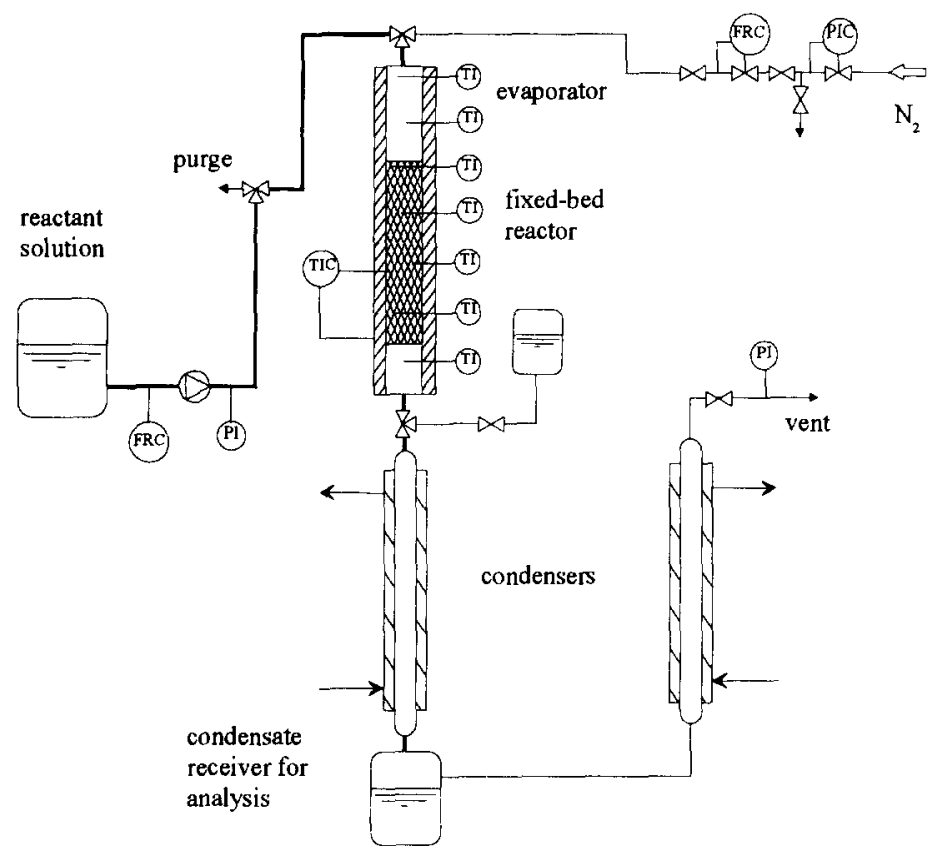

Fig. 2 Schematic layout of the experimental apparatus

The reaction mixture is condensed at the reactor outlet and collected for analysis. The product distribution is determined quantitatively by HPLC: the separation is accomplished at room temperature on a Nucleosil $5 \mathrm{C}_{18}$ column (mobile phase $\mathrm{CH}_{3} \mathrm{CN}: \mathrm{H}_{2} \mathrm{O}=1: 9$ molar ratio, flow rate $=1 \mathrm{ml} \cdot \mathrm{min}^{-1}$, operating pressure $=18 \mathrm{MPa}$ ). The signals are observed with $U V$ detection at $\lambda=270 \mathrm{~nm}$.

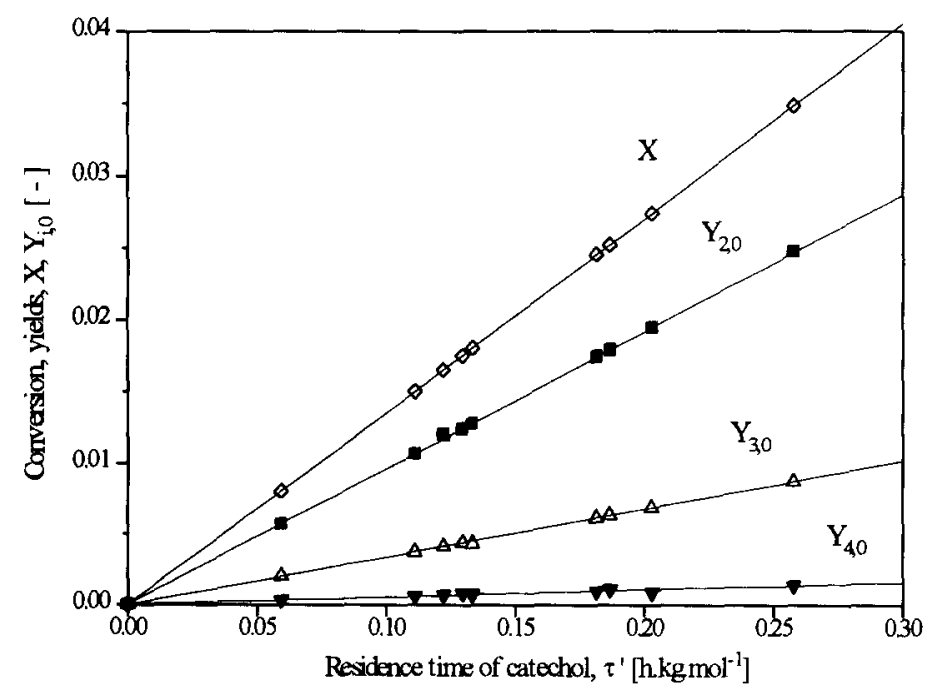

Fig.3 Differential conversion and yields on $\gamma$-alumina after initial deactivation; temperature $=270^{\circ} \mathrm{C}, \mathrm{P}_{1,0}=12.7 \mathrm{kPa}, \mathrm{P}_{5,0}=12.7 \mathrm{kPa}, \mathrm{P}_{6,0}=76.0 \mathrm{kPa}$ 
To test the different catalysts, the reaction is restricted to the primary methylation: catechol conversion is limited to values of $X<0.05$ allowing the reaction to be carried out in the differential kinetic region (Fig. 3). The standard reactants feed is a solution with a molar ratio catechol : methanol : water $=1: 1: 6$ that corresponds to initial partial pressures of $12.7 \mathrm{kPa}$ for each reactant and $76.0 \mathrm{kPa}$ for water. The initial reaction rate of catechol $\left(-R_{10}\right)$ is measured under steady-state conditions after $8-10$ hours of the catalyst activity stabilisation and is used to compare the catalysts activity. The differential selectivities $\left(s_{i, 0}\right)$ for the monomethylated products (under steadystate conditions) are used to compare the different catalysts:

$s_{i, 0}=\frac{R_{i 0}}{-R_{10}} \cong \frac{Y_{i, 0} / \tau^{\prime}}{X / \tau^{\prime}}=\frac{Y_{i, 0}}{X} \quad \quad i=2,3,4 \quad$ where $\tau^{\prime}=\frac{m_{c a t}}{F_{10}}$

\section{RESULTS}

The specific surface areas of the studied catalysts are listed in Table 1. Pure $\gamma$-alumina exhibits a B.E.T. surface area of $165 \mathrm{~m}^{2} \cdot \mathrm{g}^{-1}$. The surface areas remain almost unchanged after incorporation of $\mathrm{B}^{3+}, \mathrm{Li}^{+}$and $\mathrm{Mg}^{2+}$ with $5 \%$ of ion content (atomic-\%) but decrease in the case of $\mathrm{Ca}^{2+}$ and $\mathrm{K}^{+}$. A reduction of this area is also observed with higher $\mathrm{Mg}^{2+}$-content: the pore size distribution shows a small decrease of the average mesoporous diameter for modified $\gamma$-alumina and a global decrease of all diameters with ion content higher than $7.5 \%$

Table 1

Characteristics of the different catalysts

\begin{tabular}{|lc|c|c|c|c|c|}
\hline Catalyst & Ion content & $\begin{array}{c}\text { Specific B.E.T. } \\
\text { area } \\
\left(\mathrm{m}^{2} \cdot \mathrm{g}^{-1}\right)\end{array}$ & $\begin{array}{c}\text { Initial rate } \\
-\mathrm{R}_{10} \\
\left(\mathrm{~mol} \cdot \mathrm{kg}^{-1} \cdot \mathrm{h}^{-1}\right)\end{array}$ & \multicolumn{3}{|c|}{ Differential selectivities } \\
(atomic - \%) & $\mathrm{s}_{2,0}$ & \multicolumn{3}{|c|}{$\mathrm{s}_{3,0}$} & $\mathrm{~s}_{4,0}$ \\
\hline$\gamma-\mathrm{Al}_{2} \mathrm{O}_{3}$ & - & 165 & 0.135 & 0.71 & 0.26 & 0.03 \\
$\mathrm{~F}^{-} / \gamma-\mathrm{Al}_{2} \mathrm{O}_{3}$ & 7.5 & 144 & 0.132 & 0.70 & 0.25 & 0.05 \\
$\mathrm{~B}^{3+} / \gamma-\mathrm{Al}_{2} \mathrm{O}_{3}$ & 5 & 171 & 0.144 & 0.75 & 0.24 & 0.01 \\
$\mathrm{Ca}^{2+} / \gamma-\mathrm{Al}_{2} \mathrm{O}_{3}$ & 5 & 146 & 0.006 & 0.74 & 0.24 & 0.02 \\
$\mathrm{~K}^{+} / \gamma-\mathrm{Al}_{2} \mathrm{O}_{3}$ & 5 & 150 & 0.001 & 0.70 & 0.25 & 0.05 \\
$\mathrm{Li}^{+} / \gamma-\mathrm{Al}_{2} \mathrm{O}_{3}$ & 5 & 171 & 0.055 & 0.60 & 0.39 & 0.01 \\
$\mathrm{Mg}^{2+} / \gamma-\mathrm{Al}_{2} \mathrm{O}_{3}$ & 5 & 167 & 0.113 & 0.34 & 0.62 & 0.04 \\
$\mathrm{Mg}^{2+} / \gamma-\mathrm{Al}_{2} \mathrm{O}_{3}$ & 7.5 & 156 & 0.092 & 0.30 & 0.66 & 0.04 \\
$\mathrm{Mg}^{2+} / \gamma-\mathrm{Al}_{2} \mathrm{O}_{3}$ & 10 & 140 & 0.043 & 0.53 & 0.44 & 0.03 \\
\hline
\end{tabular}

\section{Differential reactor: catalyst screening}

After a stabilisation period of 8-10 hours, activity of $\gamma$-alumina and modified $\gamma$-alumina catalysts remains constant. The catalytic activity, expressed by the initial reaction rate $\left(-R_{10}\right)$, and the differential selectivities $\left(s_{i, 0}\right)$ on pure $\gamma$-alumina and on various modified catalysts at $270^{\circ} \mathrm{C}$ (Table 1 ). Catalysts modified with $\mathrm{F}^{-}, \mathrm{B}^{3+}, \mathrm{C}^{2+}$ and $\mathrm{K}^{+}$ exhibit the same product selectivities as pure $\gamma-\mathrm{Al}_{2} \mathrm{O}_{3}$ whereas their activity is decreased. This lost of activity depends on the ion type used and is particularly severe for $\mathrm{Ca}^{2+}$ and $\mathrm{K}^{+}$.

With $\mathrm{Li}^{+}$-modified catalysts, a remarkable selectivity increase for the desired 3-methylcatechol is observed But the most significant change is obtained with $\mathrm{Mg}^{2+}$-modified catalysts: the differential selectivity $\mathrm{s}_{3,0}$ can be improved up to 0.65 .

Deactivation

Under differential conditions pure $\gamma$-alumina and $\mathrm{F}^{*}, \mathrm{~B}^{3+}, \mathrm{Ca}^{2+}, \mathrm{K}^{+}$and $\mathrm{Li}^{+}$-modified catalysts deactivate without influencing the differential selectivities. In the case of $\mathrm{Mg}^{2+}$-modified catalysts, it is interesting to notice that the differential selectivities change during the first hours on stream (Fig. 4): the selectivity for 3-methylcatechol increases while the relative formation of guaiacol is reduced. The effect of this pre-treatment, which is always favourable to the desired product, is more or less important depending on $\mathrm{Mg}^{2+}$ content. 


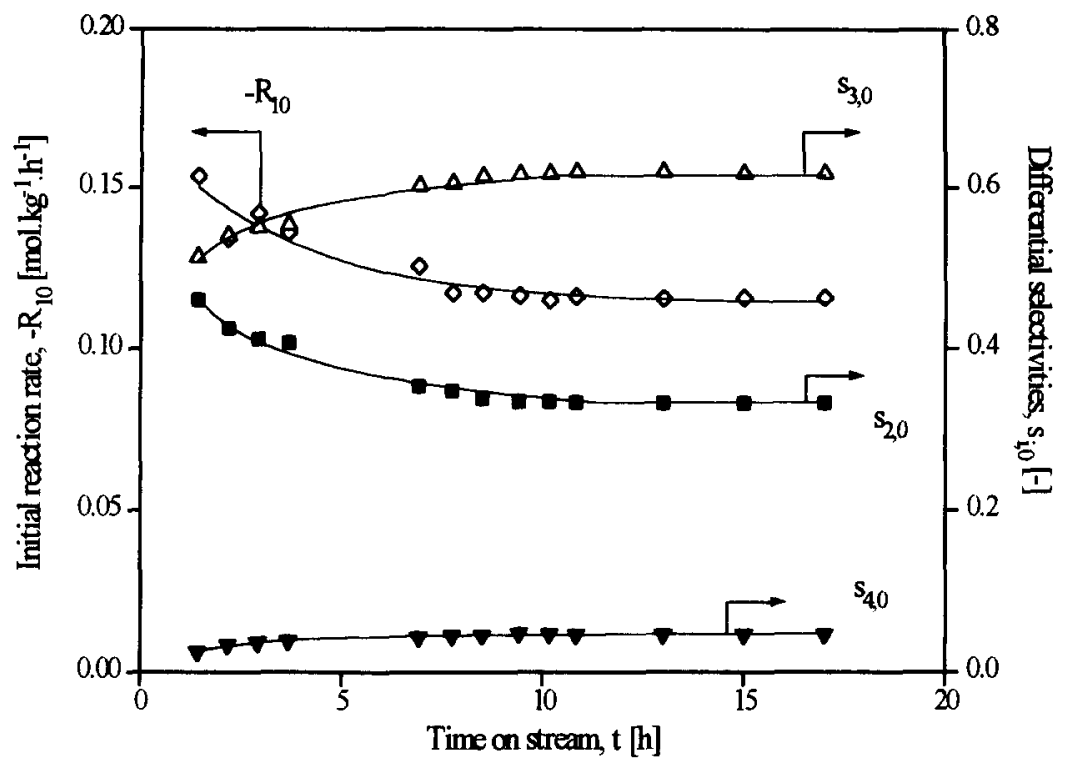

Fig.4. Deactivation of $\mathrm{Mg}^{2+} / \gamma-\mathrm{Al}_{2} \mathrm{O}_{3}(5 \%)$ catalyst; temperature $=270^{\circ} \mathrm{C}$, $P_{1,0}=12.7 \mathrm{kPa}, \mathrm{P}_{5,0}=12.7 \mathrm{kPa}, \mathrm{P}_{6,0}=76.0 \mathrm{kPa}, \tau^{\prime}=0.38 \mathrm{~h} \cdot \mathrm{kg} \cdot \mathrm{mol}^{-1}$

Catalysts modified with $\mathrm{Mg}^{2+}$

$\mathrm{Mg}^{2+}$-modified $\gamma$-alumina is of particular interest due to the fact that 3-methylcatechol selectivity increases with respect to pure $\gamma$-alumina without big lost of catalytic activity (table 1 ). The selectivity $s_{3,0}$ is strongly dependent on the $\mathrm{Mg}^{2+}$-content (Fig. 5). In the concentration range of $5-7.5 \%$ of $\mathrm{Mg}^{2+}$, it passes through a maximum of $\mathrm{s}_{3,0}=$ 0.65 and 3-methylcatechol becomes the main product under differential conditions. It is worthwhile to note that only the relative formations of guaiacol and 3-methylcatechol are affected by the percentage of $\mathrm{Mg}^{2+}$ added to $\gamma$-alumina: the oxygen-alkylation is reduced in favour of carbon-alkylation, but the ring methylation stays largely ortho-selective. The behaviour of these $\mathrm{Mg}^{2+}$-modified catalysts is very sensitive to the purity of the reactants.

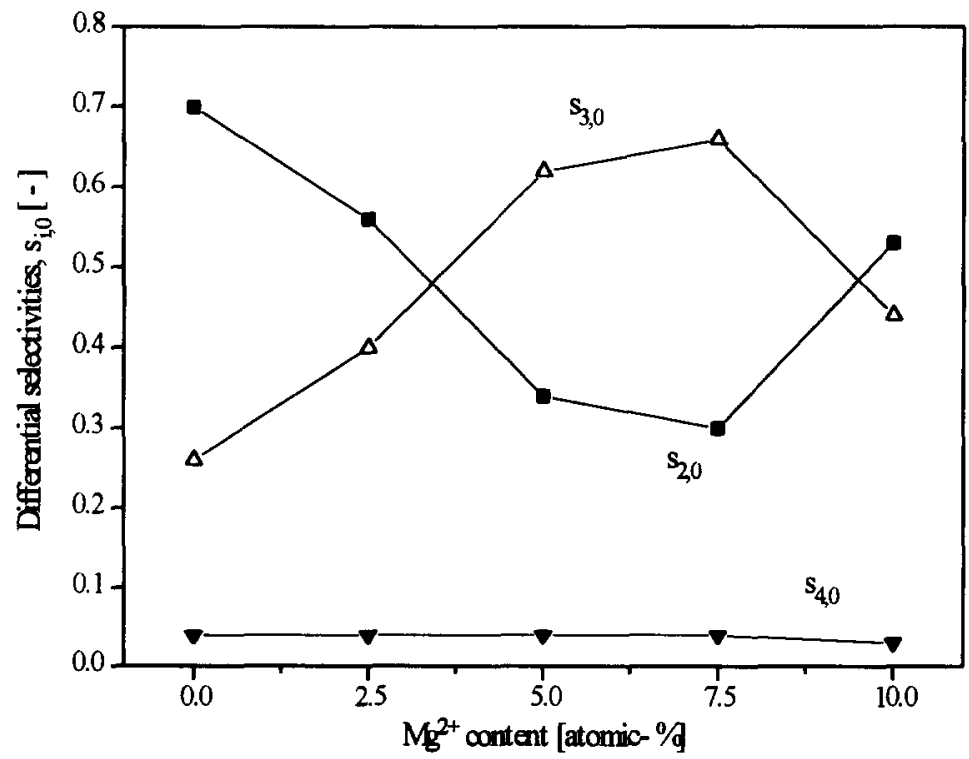

Fig.5 Differential selectivities of the monomethylated products as function of $\mathrm{Mg}^{2+}$ added to $\gamma-\mathrm{Al}_{2} \mathrm{O}_{3}$; temperature $=270^{\circ} \mathrm{C}, \mathrm{P}_{1,0}=12.7 \mathrm{kPa}, \mathrm{P}_{5,0}=12.7 \mathrm{kPa}, \mathrm{P}_{6,0}=76.0 \mathrm{kPa}, \tau^{\prime}=0.38 \mathrm{~h} \cdot \mathrm{kg} \cdot \mathrm{mol}^{-1}$ 


\section{Integral reactor}

As presented in Fig. 1, the three monomethylated isomers are formed by direct alkylation of catechol with methanol. The formation rate of 4-methylcatechol is slow compared to the production rates of the other species which is favourable because it is an undesired stable product. On the other hand guaiacol is itself a methylation agent: it decomposes in a reverse reaction to catechol and methanol or can be transformed by rearrangement to the desired 3-methylcatechol (Porchet et al, 1994). Therefore the overall yield $\mathrm{Y}_{2}$ shows the typical reaction path of an intermediate product. The yield of 3-methylcatechol increases with catechol conversion whereas the guaiacol yield passes a maximum value as shown for pure $\gamma$-alumina in Fig. 6.A). However the monomethylated products react with alkylation agents to form stable higher methylated species. The reaction has therefore to be stopped at an optimal conversion.

As the differential selectivity of 3-methylcatechol is considerably improved using $\mathrm{Mg}^{2+}$-modified catalysts, the obtainable integral selectivity can be increased to values up to 0.75 for a catechol conversion of $X=0.28$. This corresponds to a $150 \%$ higher yield compared to pure $\gamma$-alumina at the same conversion as shown in Fig. 6.b).
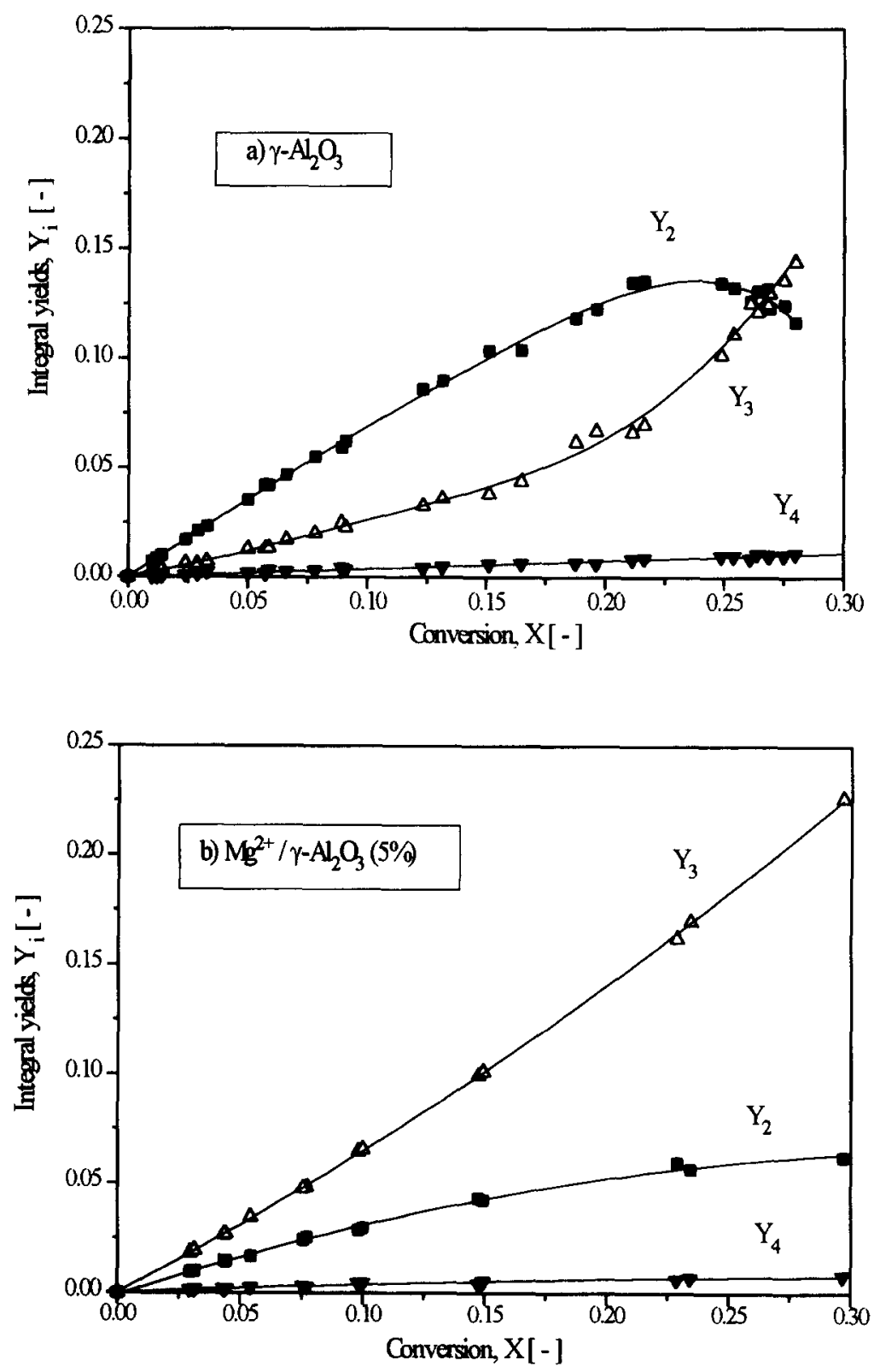

Fig. 6.a) \& b) Integral yields of the three monomethylated products as function of catechol conversion; temperature: $262^{\circ} \mathrm{C}(\mathrm{a}), 270^{\circ} \mathrm{C}(\mathrm{b}), \mathrm{P}_{1,0}=12.7 \mathrm{kPa}, \mathrm{P}_{5,0}=12.7 \mathrm{kPa}, \mathrm{P}_{6,0}=76.0 \mathrm{kPa}, \tau^{\prime}=0.3-5.7 \mathrm{~h} \cdot \mathrm{kg} \cdot \mathrm{mol}^{-1}$ 


\section{CONCLUSION}

On pure $\gamma$-alumina the selectivity for the desired product 3-methylcatechol can be optimised taking into account the initial formation rates of the monomethylated compounds and the consecutive rearrangement of guaiacol. This leads to a selectivity $s_{3}=0.52$ at a conversion of $X=0.28$. Guaiacol and catechol must then be separated and may be recycled.

It has been shown that the differential selectivity for 3-methylcatechol can be increased by modifying the catalyst with $\mathrm{Mg}^{2+}$. This leads to a selectivity $\mathrm{s}_{3}=0.75$ at the same conversion and it decreases the amount of guaiacol that has to be recycled.

\section{ACKNOWLEDGEMENT}

The authors gratefully acknowledge financial support by the Swiss National Science Foundation

\section{NOMENCLATURE}

$\begin{array}{ll}\mathrm{F}_{0} & \text { total molar flow } \\ \mathrm{F}_{10} & \text { molar flow of catechol } \\ \mathrm{m}_{\mathrm{cat}} & \text { catalyst mass } \\ \mathrm{P}_{\mathrm{i}, 0} & \text { initial partial pressure of } \mathrm{i} \\ \mathrm{R}_{\mathrm{i} 0} & \text { initial formation rate of } \mathrm{i} \\ -\mathrm{R}_{10} & \text { initial reaction rate of catechol } \\ \mathrm{S}_{\mathrm{i}} & \text { selectivity of } \mathrm{i} \\ \mathrm{s}_{\mathrm{i}, 0} & \text { differential selectivity of } \mathrm{i} \\ \mathrm{t} & \text { time on stream } \\ \tau & \text { residence time of catechol } \\ \mathrm{X} & \text { catechol conversion } \\ \mathrm{Y}_{\mathrm{i}} & \text { integral yield of } \mathrm{i} \\ \mathrm{Y}_{\mathrm{i}, 0} & \text { differential yield of } \mathrm{i} \\ \mathrm{indices} \mathrm{i}: & \\ 2 & \text { guaiacol } \\ 3 & \text { 3-methylcatechol } \\ 4 & \text { 4-methylcatechol } \\ 5 & \text { methanol } \\ 6 & \text { water }\end{array}$

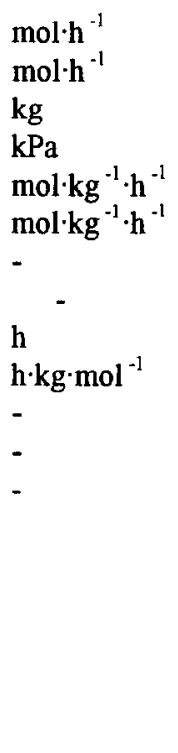

\section{REFERENCES}

Berteau, P., Ceckiewicz, S., Delmon, B., Role of the Acid-Base Properties of Aluminas, Modified $\gamma$-Alumina, and Silica-Alumina in Butanol Dehydration, 1987, Appl. Catal., 31, 361.

Berteau, P., Delmon, B., "Modified Aluminas: Relationship Between Activity in 1-Butanol Dehydration and Acidity Measured by $\mathrm{NH}_{3}$ TPD”, 1989, Catal. Today, 5, 121.

Fiege, H., Hamamoto, T., Iwata, T., Buysch, H.-J., Garbe, D., Paulus, W., Phenol Derivatives, in Ullmann's Encyclopedia of Industrial Chemistry, Vol. A19, VCH Verlagsgesellschaft, Weinheim, 1991, 313.

Jurczyk, K., Kania, W., Base Properties of Modified $\gamma$-Alumina, 1989, Appl. Catal., 56, 203.

Lercher, J. A., Colombier, C., Noller, H., Acid-Base Properties of Alumina-Magnesia Mixed Oxides, 1984, $J$. Chem. Soc., Faraday Trans. 1, 80, 949.

Porchet, S., Su, S., Doepper, R., Renken, A., Methylierung von Brenzcatechin in der Gasphase, 1993, Chem.-Ing.Tech. 65, 203.

Porchet, S., Su, S., Doepper, R., Renken, A., Heterogeneous Catalytic Methylation of Catechol, 1994, Chem. Eng. Technol. 17, 108.

Tanabe, K., Nishizaki, T, The Selectivity of Oxide Catalysts for the Alkylation of Phenols with Methanol, in Proceedings of the Sixth Congress on Catalysis, vol. 2, London, 1977, 863.

Velu, S., Swamy, C.S., Alkylation of Phenol with Methanol over Magnesium-Aluminium Calcined Hydrotalcites, 1994, Appl. Catal., 119, 241. 